УДК 902 https://doi.org/10.24852/2587-6112.2021.6.112.116

\title{
СРЕДНЕВЕКОВАЯ ГЛИНЯНАЯ ПОСУДА КАК ОПРЕДЕЛИТЕЛЬ ЭТНОКУЛЬТУРНОГО СОСТАВА НАСЕЛЕНИЯ
}

\author{
(С2021 г. М.С. Купцова
}

В данной статье рассматривается средневековая посуда, обнаруженная на территории средневековых городов Волжской Болгарии. Проводится технико-технологический анализ и сравнительная характеристика этнокультурных групп посуды, приводится статистическая таблица наличия каждой группы керамики на каждом памятнике. На основе анализа вещественных материалов автор связывает их этнокультурными группами, выявляет их взаимодействие и влияние на местное болгарское население. Изучение данной проблемы имеет большую актуальность в свете развернувшейся в научных кругах полемики об этнокультурном составе населения региона в домонгольской и золотоордынский периоды. Слабость письменных источников по данной проблеме, в значительной мере, компенсируется археологическим материалом, наиболее содержательным и информативным из которого являются керамические комплексы. Керамика прикамско-приуральского населения, которая волнами проникало на территорию Волжской Болгарии с востока начиная с середины X века, в свое время была выделена T.A. Хлебниковой в VII и VIII группы своей классификации. Автор отмечает, что посуда данного населения присутствует во всех памятниках Нижнего Прикамья домонгольского периода. Но наиболее ярко она представлена в средневековых городищах Алабуга, Кирмени, Чаллы и Старое Ромашкино.

Ключевые слова: археология, Волжская Болгария, средневековье, городище, группа керамики, орнамент, формовка.

\section{MEDIEVAL CLAYWARE AS A DETERMINANT OF THE ETHNIC- CULTURAL COMPOSITION OF THE POPULATION}

\section{M.S. Kuptsova}

The paper concerns the medieval ware discovered in the territory of the medieval towns of Volga Bolgaria. Technical and technological analysis and comparative characteristics of the ethnic-cultural types of ware are provided, and a statistical table indicating the presence of each type of ceramics at each site is included. Based on the analysis of material items, interrelation of the ethnic-cultural groups is established by the author, and their interaction and influence on the local Bolgar population is outlined. The study of this issue is of great urgency in view of the discussion in the scientific world regarding the ethnocultural composition of the region's population in the Pre-Mongol and Golden Horde periods. The scarcity of written sources related to the issue is largely compensated by archaeological material, the most substantial and informative of which are ceramic complexes. The ceramics of the Kama-Ural population whose waves penetrated the territory of Volga Bolgaria from the East since the mid-10th century was determined by T.A. Khlebnikova as belonging groups VII and VIII according to the researcher's classification. It should be noted that this population's ware is present at all sites of the Lower Kama region of the Pre-Mongol period. But it is most vividly present in the medieval hillforts Alabuga, Kirmen, Chally and Staroe Romashkino.

Keywords: archaeology, Volga Bolgaria, Middle Ages, hillfort, ceramic group, ornament, molding.

$\mathrm{X}$ век, ознаменовавшийся для Поволжья падением Хазарского каганата и образованием на территории Поволжья нового централизованного государства Волжская Болгария, ввел в движение многие народы, в том числе и большое количество угроязычного населения, которые активно начали заселять территорию и контактировать с местным болгарским населением. Процесс взаимодействия мы видим непосредственно в самой материальной культуре, когда среди большого обилия материалов болгарских ремесленников встре- чаются предметы, не характерные для местного производства. Примером этому служит наличие большого процента средневековой, или, как принято называть, «традиционной», керамики на памятниках Волжской Болгарии, которые являются ярким показателем этнокультурных процессов на территории всего Поволжья. Зачастую керамический материал на поселениях бывает практически единственным датирующим материалом и в связи с большим процентом его нахождения представляет собой наиболее обширный и полно- 
ценный в плане поступающей информации материал. Керамический материал может создать прочный фундамент для реконструкции истории древних обществ, развития их во времени, преемственности поколений, контактов между собой и влияния этнокультурных групп друг на друга.

В процессе работы над данной статьей были использованы общенаучные методы познания: анализ, синтез, индукция, дедукция. При написании работы применялись традиционные для исторической науки методы познания, состоящие из 3 этапов: 1. полевой (стратиграфический метод); 2. камерально-лабораторный (сравнительно-типологический метод); 3. кабинетный (метод перекрестной датировки, проблемно-хронологический, метод исторической ретроспекции).

Стратиграфический метод был применён на этапе полевых исследований Елабужского, Кирменского, Староромашкинского, Чаллынского городищ. Данный метод состоит из составления стратиграфического плана культурных напластований каждого из городищ, в установлении хронологического соотношения между ними и фиксации керамических материалов с каждого слоя. На камеральнолабораторном этапе применяется сравнительно-типологический метод, в основе которого лежит разделение на отдельные подгруппы по общим признакам: способ изготовления, состав теста, формовка теста, орнаментация и т. д. и который позволил на основе анализа материала классифицировать средневековую посуду по различным этнокультурным группам (по класс. Т.А. Хлебниковой). На основе выявленных общих признаков была произведена привязка к определенной этнокультурной группе.

На последнем, кабинетном этапе применялся проблемно-хронологический метод, который позволил вычленить внутри изучаемой проблемы целый комплекс узких проблем и проследить их трансформацию. В частности, к таким проблемам можно отнести наличие в материалах рассматриваемых памятников традиционной «гибридной» посуды или же вовсе отсутствие некоторых групп посуды.

По материалам памятников Волжской Болгарии выделяют «традиционную» посуду, или же посуду пришлого населения (табл. 1.). Для изучения данной категории посуды были проанализированы материалы со следующих городищ: Елабужское городище (г. Елабуга Республики Татарстан) расположено на правобережье устья р. Тоймы, правого притока р. Камы, на высоте 50-60 м.; Кирменское городище (Мамадышский район Республики Татарстан) расположено на высоком мысу левого берега р. Кирменки, ограничивается с запада глубоким оврагом; Чаллынское городище (Рыбно-Слободской район Республики Татарстан) расположено на высоком мысу левого коренного берега р. Шумбут, правого притока Камы, на высоте 24 м, с широким оврагом с юга-востока; Староромашкинское городище «Кала», «Калюш» (Чистопольский район Республики Татарстан) расположено в 17 км юго-восточнее г. Чистополя и в 16 км южнее р. Камы. В 500 м севернее городища находится с. Старое Ромашкино.

В работе Т.А. Хлебниковой «Керамика памятников Волжской Болгарии» (Хлебникова, 1984) проводится работа по классификации всей средневековой посуды, обнаруженной на памятниках Волжской Болгарии; на данную работу и будет сделан основной упор при классификации керамики на рассматриваемых памятниках. Всего в работе Т.А. Хлебникова выделяет 24 этнокультурные группы средневековой посуды, среди которых необходимо выделить 6 основных групп керамики, которые подлежат анализу в данной работе.

Наиболее многочисленной является I «общеболгарская» группа - 57019 фр. Посуда изготовлена из глиняного теста с примесью песка. Почти половина посуды имеет лощение и хороший обжиг. Посуда в основном коричневого - 22522 (39,5\%), красного - 15395 (27\%), желто-красного - 11661 (20,5\%), значительно меньше посуды бурого - 4561(8\%), серого - $2565(4,5 \%)$ и желтого - 285(0,5\%) цветов, по данным Кирменского городища. Глиняная посуда в сильно фрагментированном состоянии, и поэтому реконструировать ее формы достаточно затруднительно. Однако можно выделить практически все категории сосудов, которые встречаются на болгарских поселениях: горшковидные, кувшинообразные, мискообразные, чашевидные и блюдообразные. В орнаментации группы I преобладают линейные мотивы. Заметное место занимают оттиски гребенчатого штампа, «запятые» и волнообразная орнаментация по 
Таблица 1. Статистические данные «традиционно» керамики по городищам Волжской Болгарии

Table 1. Statistical data on "traditional" ceramics from the settlements of Volga Bolgaria

\begin{tabular}{|c|c|c|c|c|c|c|}
\hline $\begin{array}{c}\text { Наименование } \\
\text { памятника }\end{array}$ & $\begin{array}{c}\text { I гр. (Обше- } \\
\text { болгарская) }\end{array}$ & $\begin{array}{c}\text { II или IX } \\
\text { (керамика } \\
\text { салтово- } \\
\text { маяцких } \\
\text { истоков) }\end{array}$ & $\begin{array}{c}\text { VII («постпе- } \\
\text { трогром») }\end{array}$ & $\begin{array}{c}\text { VIIII } \\
\text { гр. }\end{array}$ & $\begin{array}{c}\text { XVII } \\
\text { гр. }\end{array}$ & $\begin{array}{c}\text { XVIII } \\
\text { гр. }\end{array}$ \\
\hline Елабужское городище & $35 \%$ & - & $1 \%$ & - & - & $2 \%$ \\
\hline Кирменское городище & $75,4 \%$ & $0,01 \%$ & $11 \%$ & - & $0,01 \%$ & $0,32 \%$ \\
\hline Чаллынское городище & $54 \%$ & $0,3 \%$ & $7,5 \%$ & - & - & - \\
\hline Староромашкинское городище & $84 \%$ & $0,01 \%$ & $8 \%$ & - & - & - \\
\hline
\end{tabular}

шейке, плечику и тулову. Имеются фрагменты с каннелюрным орнаментом. Данная группа посуды характерна для большинства памятников Волжской Болгарии (табл. 1.). Лишь в материалах Елабужского городища мы видим ее немногочисленность (табл. 1), это связано с тем, что большой процент населения, проживавшего на территории Елабужского городища, был финно-угорским, и лишь небольшая его часть -болгарской (вероятнее всего, военная знать), так как городище выполняло функцию военного форт-поста северо-восточных земель Волжской Болгарии.

Следующая категория посуды является традиционной: VII группа посуды, или посуда «постпетрогром» (по Е.П. Казакову (Казаков, 2004, с. 121)), представляет собой лепные, круглодонные сосуды с толченой раковиной в тесте. Т.А. Хлебниковой рассматривается как посуда, возникшая в Сылвенском бассейне Верхнего Прикамья в результате смешения традиций изготовления верхнекамского пермского населения и пришлого зауральско-угорского, с большим доминированием второго. В количественном отношении превалирует лишь в материалах Елабужского городища (более $60 \%$ от всего количества керамического материала (Хузин, 2008, с. 45)). В остальных же памятниках не более $10 \%$ от общего количества керамики (табл. 1).

Для данной керамики характерна веревочно-гребенчатая орнаментация по горловине и плечику (более 75\% посуды со Староромашкинского городища), нарезки по скошенному краю венчика (не более 61\%). По формам выделяются горшковидные и чашевидные сосуды; VIII группа керамики в числе домонгольской группы керамики обнаружена только на территории Староромашкинского городища. В настоящий момент существует ряд вопросов по целесообразности выделения данной посуды в отдельную этнокультурную группу, А.П. Смирнов относит ее к VII группе, только измененной в результате взаимодействия с местным болгарским населением. Данная группа представляет собой сосуды более плотного песочного теста с добавлением мелкого шамота, цилиндрошейная с резной орнаментацией. Всего в материалах Староромашкинского городища представлена 61 фрагментом (в культурных напластованиях, в сооружениях отсутствует). В процентном соотношении представлена $0,1-0,2 \%$ от общего количества керамики. Данная посуда представлена чашевидными и горшковидными формами. А.Т. Хлебникова рассматривает формирование данной группы в среде кушнаренковской посуды, только измененной в результате взаимодействия в среде местного болгарского населения; XVII группа посуды представляет собой развитие VIII группы керамики. В количественном плане составляет 61 фр., 1-2\% от общего количества керамики (в материалах Староромашкинского городища). Состав теста без заметных глазу примесей, формовка сосуда также характерна и для VIII, когда нижняя часть сосуда вылеплена вручную, верхняя часть (венчик и горловина) подправлены на гончарном круге. Среди орнаментаций превалирует однорядная (широкая) набегающая волна (что характерно также и для VIII гр.). Стратиграфически относится к более верхним слоям материалов Староромашкинского городища (XII - начало XIII вB.).

XVIII группа керамики представлена в материалах только Кирменского городища в количестве 184 фрагментов (0,32\%). Статиграфически все происходят из верхнего горизонта слоя. Керамика представлена в сильно фраг- 
ментированном виде, провести реконструкцию сосудов по формам достаточно сложно.

В настоящий момент существует достаточно много дискуссионных вопросов относительно этнокультурной привязки каждой из рассмотренных этнокультурных групп посуды. Поэтому обратимся к этнокультурной составляющей VII группы керамики, или «постпетрогромской» керамике (по Е.П. Казакову) (Казаков, 2004, с. 121). Е.П. Казаков выделяет носителей данной группы в отдельную археологическую культуру с появлением их в начале X в. Е.М. Берс объединяет их в отдельную калмацкую культуру IV-V в. н. э. (Берс, 1963, с. 26), хронологически данную версию поддержал В.Ф. Генинг, но отнес их к ломоватовской культуре (Генинг, 1961, с. 54). Т.А. Хлебникова в своей работе «Керамика памятников Волжской Болгарии...» датирует их вместе с угорским населением X в. с влиянием верхнекамского (Хлебникова, 1984, с. 78). Мы же склоны отождествлять носителей VII группы керамики с угорским населением Предуралья.

Говоря об этнической принадлежности VIII группы керамики, необходимо отметить ее отождествление Е.П. Казаковым (Казаков, 1978 с. 45) с переходным видом гребенчатошнуровой VII гр., сложившейся под влиянием болгарской гончарной посуды. Он видит их определенное сходство в составе теста и некоторых орнаментах, в частности расположении орнамента в определенных частях посуды. Если сопоставить данные группы посуды по технологическому признаку, будет следующее: по составу теста данные группы схожи, лишь в некоторых фрагментах посуды VIII группы можно обнаружить мелкий шамот. По форме сосудов есть одно определенное различие: скошенность края венчика вовнутрь у VII группы, тогда как VIII группа представлена закругленной. Орнаментация: для VII группы характерна лишь линейно-гребенчатая орнаментация, а у VIII она разбавлена однорядной набегающей волной по плечику. Что касается расположения орнамента: VII - горловина, VIII - плечико и горловина. Поэтому отождест- влять VIII группу керамики с VII мы считаем неверным по следующей причине: если VIII группа керамики является видоизмененной VII группой в результате взаимодействия с местным населением, то она должна была выделиться в материалах Елабужского городища (Елабужское городище - единственный памятник в Волжской Болгарии, где процентное соотношение VII группы относительно болгарской превалирует - 60\% от общего количества керамики), однако VIII группы на данном памятнике вовсе нет. Вероятней всего, VIII группу керамики необходимо рассматривать в рамках взаимодействия с населением «джукетауской округи», когда свойственным для данной группы населения было наличие песка в тесте, поэтапное изготовление посуды и орнаментация.

XVII группа керамики представляет собой развитие VIII так называемых приуральских истоков. Определенные черты сходства VIII и XVII групп были в свое время подмечены А.Т. Хлебниковой, указывавшей на их определенную близость - «близкая факутра теста..., производство XVII группы керамики переступили порог домашнего производства, вероятно, оно было рассчитано для определенного круга покупателей, которому были дороги традиции изготовления VIII группы керамики» (Хлебникова, 1984, с. 79). Вероятней всего, это население Нижнего Прикамья и Башкирского Приуралья.

Таким образом, на основе анализа материалов памятников Волжской Болгарии можно проследить этнокультурные процессы, протекавшие на территории Поволжья в период Средневековья. Большую роль в этом сыграло угорское население, пришедшее на территорию Волжской Болгарии в X в. Бесспорным остается факт, что рассматриваемая территория является местом, где удерживались традиционные этнокультурные технологии изготовления посуды, а частичное выделение одной группы от другой отражает развитие гончарства, а также процесс формирования единой культуры и этноса.

\section{ЛИТЕРАТУРА}

Берс E.M. Археологические памятники Свердловска и его окрестностей. Изд. 2-е, испр. И доп. Свердловск, 1963. 116 с.

Генинг В.Ф. Проблемы изучения железного века Урала // ВАУ. Вып.1 / Отв. ред. В.Ф. Генинг. Свердловск, 1961. С. 23-47. 
Казаков Е.П. Памятники болгарского времени в восточных районах Татарии. М.: Наука, 1978. 103 с.

Хлебникова Т.А. Керамика памятников Волжской Болгарии. К вопросу об этнокультурном составе населения. М.: Наука, 1984. 241 с.

Хузин Ф.Ш. К вопросу о так называемой «постпетрогромской» культуре // Камский торговый путь: материалы Всерос. Науч-практ. Конф. Елабуга: Изд-во Елабуж. гос. пед. ин-та, 2008. С. 11-22.

Казаков Е.П. Постпетрогромская культура: истоки, время, территория // Четвертые Берсовские чтения / Отв. ред В.М. Морозов. Екатеринбург: Квадрат, 2004. С. 120-128.

\section{Информация об авторе:}

Купцова Мальвина Стансилавовна, заведующая лабораторией археологии и этнографии, Елабужский институт Казанского (Приволжского) федерального университета (г. Елабуга, Россия); malvina2711@bk.ru

\section{REFERENCES}

Bers, E. M. 1963. Arkheologicheskie pamiatniki Sverdlovska i ego okrestnostei (Archaeological Monuments of Sverdlovsk and its Neighbouring Area). Sverdlovsk (in Russian).

Gening, V. F. 1961. In Gening, V. F. (ed.). Voprosy arkheologii Urala (Problems of Archaeology of Ural) 1. Sverdlovsk, 23-47 (in Russian).

Khuzin, F. Sh. 2008. In Kornilova, I. V. et. (eds). Kamskii torgovyi put'(Kama Trade Route). Elabuga: Elabuga State Pedagogical university, 11-22 (in Russian).

Kazakov, E. P. 2004. In Morozov, V. M. (ed.). Chetvetye Bersovskie chteniia (Fourth Bers Readings). Yekaterinburg: "Kvadrat" Publ., 120-128 (in Russian).

Khlebnikova, T. A. 1984. Keramika pamiatnikov Volzhskoi Bolgarii: (K voprosu ob etnokul'turnom sostave naseleniia) (Ceramic Ware ft he Volga Bolgaria Sites. On the Issue of Ethnic and Cultural Composition of the Population). Moscow: "Nauka" Publ. (in Russian).

Kazakov, E. P. 1978. Pamiatniki bolgarskogo vremeni v vostochnykh raionakh Tatarii (Sites of Bolgar Time in the Eastern Parts of Tataria). Moscow: "Nauka" Publ. (in Russian).

\section{About the Author:}

Kuptsova Malvina S. Yelabuga Institute of Kazan (Volga Region) Federal University. Elabuga, Russian Federation malvina2711@bk.ru 